\title{
Cooperative Learning Group for English Teachers: A School-based Teachers' Professional Development
}

\author{
Puji Rahayu and Irma Windy Astuti \\ Islamic University of Indonesia
}

\begin{abstract}
The process of civil servant teacher's recruitment makes a school to possibly have both, or either, qualified and under qualified English teachers. The former can observe their job as teachers well while the later might not. The case is worse when they are not only incapable of teaching well but also still need help in their English proficiency. Asking them to take an English class is almost impossible. There must be ways of developing their professionalism while they are performing their tasks as teachers.

Building a cooperative learning group for English teachers will improve their professionalism, both the qualified and under qualified ones, with its very slogan "sink and swim together". Each group will be responsible for the improvement of all members because their success is determined by the success of the group and the group also determines the success of the individual. Being in this group, qualified teachers can help their friends with their experiences while those who are not lucky in terms of both English and teaching skills will benefit from them without feeling underestimated due to the individual accountability characteristic of cooperative learning.

In the group, teachers can do various professional development activities. They can build a discussion group, a reading group, peer observation and team teaching, and conduct a collaborative action research. This group will work better if the head master or a coordinator keeps an eye on it. This movement will also be much more effective if it is used as one of the criteria of kenaikan pangkat.
\end{abstract}

Key words: cooperative learning, English teacher, profession development 


\section{A. Cooperative Learning}

\section{A.1. Definition, Characteristics and Benefits}

Cooperative learning (CL) is widely and generally known as an approach of learning which implement cooperation in education. For many years, CL has received profound attentions from scholars, researchers, and teachers who examine its effects toward learning.

According to Olsen and Kagan (1992), there is, however, no universally acceptable definition of cooperative learning. Olsen and Kagan as cited in Kessler 1992) particularly define cooperative learning as the following;

Cooperative leaming is a group learning activity organized so that learning is dependent on the socially structured exchange of information between learners in groups and in which each learner is held accountable for his or her learning and is motivated to increase the learning of others (p.8

The use of CL then implies a group of people working together instead of in isolation in a structured and organized way to ensure that everyone is able to take responsibility of his or her own learning and others' as well. It also appears that the implementation of $C L$ in any disciplines and levels of education requires each of its participants to play an active role in engaging him/herself and others throughout the activity. This is in line with what Brown sees as one of the key elements in CL classroom in which according to him, classroom that is cooperative usually involves learner-centered characteristics as "learners work together in pair or groups, they share information and come to each other's aid"(Brown, 2001).

in other words, learners would likely to benefit from cooperative learning since their groupings and group works would not only allow them to have more opportunity to actively participate in learning as individuals, but also help others to grow. The mutual relationship among CL learners is what seemingly contributes to other positive implications of CL use. As cited in Brown, Oxford views cooperative learning as "promoting intrinsic motivation,...heighten self esteem,...creating caring and altruistic relationships, and lowering anxiety and prejudice"(1997:445).

Furthermore, Bassano and Christison (1998) have also noted some other important benefits of CL. There are among others associated with its ability to assist with social tasks, selecting content, setting goals, and assist in monitoring progress of evaluative task of its participant. 


\section{A.2. Cooperative Learning Group for Teachers}

Many bodies of literature and researches have mostly been associating the benefits of CL with interaction among students. However, teachers or in this case language teachers might also benefit from using CL as a means and process of upgrading themselves

Language teachers around the world might have been quite familiar with the principles and the implementation of Cooperative Leaming in their language class. However, the question is, are teachers equally aware of its benefits for their sake. Have they ever thought that CL can help them learn, change and grow the way their students learn within the same framework? But, why is Cooperative Learning for teachers? It is generally known that while learning can be conducted almost anytime and anywhere, it is almost impossible for learning to take place in isolation. In other words, people need other people to leam something. Social . system theory emphasizes the importance of human interaction, encouraging democratic interaction and open communication in order for meaningful dialogue and problem solving to take place (Hanson, 1991). Therefore, teachers need their colleagues in some ways to assist their learning. This is especially true in the case of novice teacher whose notion of teaching and learning still need to be continuously redefined due to his or her yet limited experience. In this case, he/ she can collaborate and work cooperatively with more senior and experienced teacher with whom he/she can share ideas, knowledge, and experiences while reflecting on each others' teaching practice.

\section{B. Teachers Professional Development \\ B.1. Definition}

In broader sense, professional development may be understood as an individual's growth within his/her profession which is indicated by his developed or growing professionalism. More specifically Maggioli (2003).sees professional development as an evolving process of professional self-disclosure, reflection, and growth that yields the best results when sustained over time in communities of practice and when focused on job-embedded responsibilities. So, anyone aiming at being a professional should aware that it comes with continuous learning and responsibility. As for language teacher, a professional development is a 
professional growth a teacher achieves as a result of gaining new experience and examining his/ her teaching systematically (Glatthorn, 1995, p.41).

\section{B.2. Why and how to develop teachers' professionalism}

Teaching cannot simply be seen as an occupation. Teachers are professionals as opposed to mere workers. Teaching holds professional values and therefore teachers' professionalism is what every language teachers should have. Jackson (1987) sees teaching as essentially important for the well-being of society and of the individual. Thus, it is not too much to say if teacher is considered as an agent of change (Brown, 2001). However, in order to be one, teacher needs to be willing to change him/herself for the better.

Another reason for engaging teachers in a sustained professional development is due to many factors. It is the rapid changes that occur in the teaching profession that require teachers to keep up and to be well-informed with the latest insight and innovation in language teaching. Thus, similarly to students, teachers too need to grow overtime. In addition, the need to upgrade one self may be intended to improve an individual teaching expertise and/or to rise in their teaching professions. Like in Indonesia nowadays, as the government launched teachers' certification, the Indonesian teachers are held responsible to upgrade him/herself.

In the mean time, teachers professional development may be achieved through formal experience (such as attending workshop, training, conference, or mentoring) or/ and informal experiences (such as reading professional publication, watching documentaries, or peer sharing) (Ganser, 2000). Thus, teachers professional development can take many forms, and in order for teachers to develop effectively, they would ideally need to have access to all of the above experiences.

\section{Teachers' professionalism using Cooperative Learning Principles. C.1. Rationale}

Teachers engagement in professional development may be facilitated with many options. According to Paul Davies, they may be grouped into three broad categories: Self-development, Cooperative Development, and Formal Development (2000, p.197). This paper proposes that an English teacher can get 
enormous benefits by way of using the principles of cooperative learning in their attempt to upgrade him/ herself while developing his/her other fellow teachers. This joint participatory style of learning. will not only contribute to a better understanding of one's profession, but also offer opportunities for teacher to develop a sense of community ethos; sense of belonging, working together, taking risks, and encouraging each other (Moberly, 1996). Teachers' cooperative learning group can therefore be a place where teachers seek for each other's support and suggestions. Furthermore as cited in Reimers (2003), one of the new perspectives and characteristics of effective teachers' development is conceived through collaborative process (Darling-Hammond and McLaughlin, 1995) and occurs when there are meaningful interactions (Clement and Vanderberghe, 2000). Hence, it is clear that professional development cannot be done all alone.

As some ways of developing teachers mentioned above, we, as teachers, can choose which one is appropriate. When we are not sure yet which ways to develop, the figure below is worth trying. Simply put number 1 to 12 on the left side to indicate what actually happens and on the right side we re-prioritize the item as what we would like them to be.

\begin{tabular}{|c|}
\hline Attending conferences \\
\hline Getting a certificate/diploma/degree \\
\hline Peer observation \\
\hline Peer counseling (time spent talking to colleagues) \\
\hline Lesson planning/creating materials \\
\hline Reading professional journals/books \\
\hline Time.with students (outside classroom) \\
\hline Time getting to and from place of work \\
\hline Writing articles \\
\hline Syllabus design/writing a (text) book \\
\hline Doing (classroom) action research \\
\hline Doing administrative duties \\
\hline
\end{tabular}

Professional Priorities of Bawcom (in Harmer, 2007:412) 
After comparing the left number to the right one, we can know which one should be of priority for our development. Giving 12 to an item means that we should put it as the highest priority.

When carrying out the development, we have to be highly motivated and determined, otherwise, the process will be of no points. To keep the motivation, hence, we have to establish a group, consisting of teachers having the same intention to develop their professionalism. They can be from some schools, like PGRI which is a professional organization for teachers, and subject matters, like MGMP as a formal teachers gathering to discuss things related to a specific subject taught by them. In this paper, however, we propose a group called cooperative learning group for English teachers in one school.

\section{C.2. What is the design like?}

What we mean by cooperative leaming group here is a group consisting of English teachers in a specific school. The group can be as small as three or as big as six teachers. This group will work together hand in hand to develop their skills in teaching English. As the very characteristic of cooperative learning is "sink and swim together", teachers will always help the members who are not very good yet at teaching so as to reach their goal. It is believed to happen because the success of the group is determined by the success of the members so that they will never leave those struggling in teaching alone.

In a certain period of time, it can be in one semester, the group will carry out some activities related to enhancing their skill in teaching English on daily basis. The activities are, but not limited to, reading group, peer teaching and peer observation, collaborative action research, and workshops. The activities can be done either involving only the group members or more people from different groups, depending on the scope of the theme. Yet, more specific theme activities should be conducted more often involving only the group member to make it more effective. The more complete explanation on how the activities should be carried out will be discussed in the next section of this paper.

The group will work more effectively under the head master's support and supervision. (I believe this will give more works to the head master but everything for the school improvement should be of the highest priority). Support can be given by applying policies giving the teachers more "space" to have those professional development activities. Teachers should not be given too many classes beyond 
their capacity and scheduling should also be in line with the programs the group is proposing. Besides, facilities that the teachers need should be available.

Although supports have been given, however, the result might not be maximum if there is no supervision from the head master. The supervision, or we can also mean it as assessment, can be done by the head master himself or he can assign a team responsible for it. The assessment criteria must be related to the concept of evaluation in cooperative learning. It is not only individuals' but also the group improvement should be considered. The improvement must not be assessed based on the outcome but from the process.

To make the assessment result more reliable and valid, the school can involve the students and other school members. The assessment from other members of the schools can be derived from a survey. Students can be asked to comment on the teachers' performance in class, other teachers form different group can be asked to comment on the social skills of the teachers, while the administrative staffs are asked to comment on how the teachers use the school facilities. The evaluation should not be done only once a year but it should be more often so as to get more data. In order that the process will run successfully and make the teachers more motivated, the result of the assessment can be used to determine the angka kredit for kenaikan pangkat.

\section{C.3. Activities to be carried Out in the Group and the Procedure}

The evaluation above is done to know the improvements the teachers have achieved after undergoing a process within the group. The process will include the activities which are to be discussed in the following section.

\section{C.3.1. Reading/discussion Group}

As stated by Brown (2001:430), a good teacher should always keep up with the new trends in the field by reading books. Due to many jobs, however, teachers often claim that they do not have time to read books. There must be other teachers who will always remind them to always read books or keep up with the new trend. Making a group is very important in this case.

We are proposing cooperative learning group to let every group member read books in a regular basis. The reading activity is done in group using a variation of the jigsaw method. 
First, the group decides what books to read in a certain period of time. After that, the coordinator divided the chapters to the members of the group to read in a certain period of time. Each group member should get one complete chapter so that the understanding is not broken down. On the agreed day, the group meets to discuss what has been read. Each group member tells the group the content of the chapter they read. When retelling, they should bring and always refer to the books so that if the explanation is not very clear, the other group member can help by referring to the book.

\section{C.3.2. Workshops}

The workshop we are proposing here is not a large scale one but a workshop attended by only the group members. The workshops can be from the idea taken from the reading group. When the group has just finished reading a book on methodology, for example, it can conduct a workshop on the application. The group can have it presented by one of the group member or it can ask someone else outside the group to give the workshop.

The result of the workshop is expected to be more fruitful when attended only by small number of people since all participants can have a try on the methodology or other theme of the workshop. Once, I experienced a workshop on the use of new media ELTI produced and had a try to use the media. It is more valuable for me because I could use the media well by the clear instruction and attention given by the facilitator. At first, I found difficulty but then the facilitator helped me. When the participants of the workshop are too many, I believe that not all par icipants will get enough attention from the facilitator.

\section{C.3.3. Peer Observation and Peer Teaching}

After having a workshop on a new method or things related to the teaching, two teachers can arrange a peer observation and teaching. It is actually not a new idea when a teacher is being observed by the head or pengawas when teaching in the class but this method of observation is quite frightening for the teacher because $\mathrm{s} /$ he is assessed. The purpose of the observation is not for improvement but judgment whether the teacher is performing well or not.

Peer observation in a cooperative learning, however, is done with a sole purpose of bettering the way the teacher teaches in the class. There are some procedures that can be used. 


\section{C.2.4. Collaborative Action Research}

Action Research is the process through which teachers collaborate in evaluating their practice jointly; raise awareness of their personal theory; articulate a shared conception of values; try out new strategies to render the values expressed. in their practice more consistent with educational values they espouse; record their work in a form which is readily available to and understandable by other teachers; and thus develop a shared theory of teaching by researching practice (John Elliott: 1993). In other words, action research can be done only if teachers collaborate with others, which can be other teachers or school members, and it is done to ensure the teachers' own theory in teaching by trying out the belief in their class so that they can prove their the success of the new strategies which is supported by carefully recorded data:

Doing action research in the cooperative learning group, teachers can benefit from the reflective characteristics of conducting action research to develop their professionalism. Teachers can start from the feedback of the peer observation, if there are things to improve in the class. Teachers can discuss the feedback, either with the observing teacher or the group, about what strategies to be carried out to solve the problem. During the discussion, other members might. share their experiences that might be useful for the teacher.

We may conclude that action research is open-ended. When a problem has been taken care of after a series of planning, doing, evaluating and acting, another problem might possibly happen. And we start from the beginning again so solve the problem. The summary of the steps will be like the diagram below

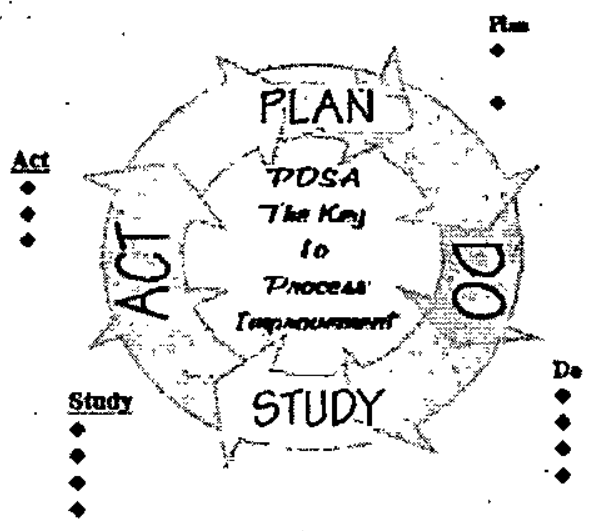


We can see from the diagram above that there is no end in action research since a certain cycle is always followed by another and another. This is actually the same as the life philosophy. Life is always full of problems that we have to solve. The most important is not being perfect but being improved. That's why action research is very useful for professional development since in action research teacher always does what we call reflection. It is about seeing what we have done, whether it is in line with what we want or no. Nunan, in Hall and Hewing, states that an important concept underpinning action research is that of reflective practice. In addition to Nunan, in his excellent book on reflective teaching, Wallace (1991) argues that reflective teaching provide a way of developing professional competence by integrating two sources of knowledge, received knowledge and experiential knowledge, with practice. His conception is captured in the figure below

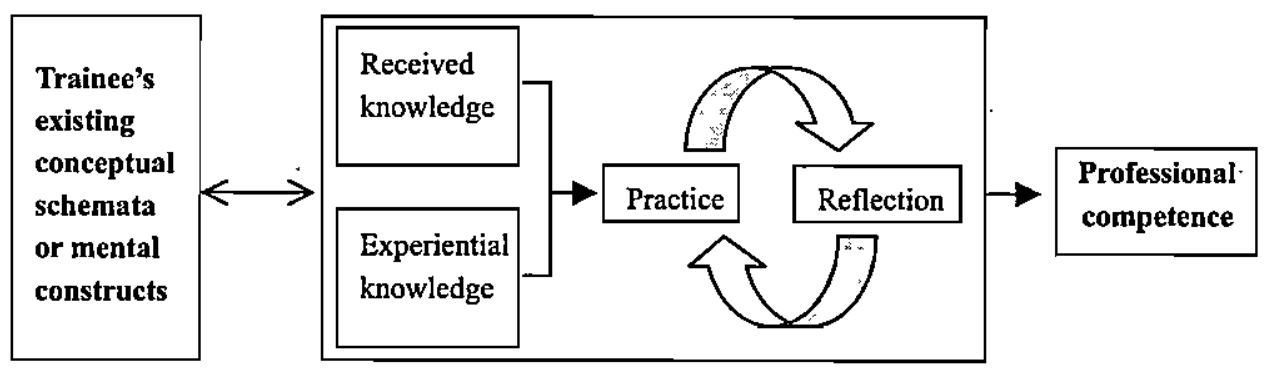

\section{Teacker Observation Form *}

Keep in mind these criteria when observing a teacher. Circle or check each item in the column that most clearly represents your evaluation: 4=excellent, 3=above average, 2=average, $1=$ unsatisfactory, N/A=not applicable. You may also write comments in addition to or in lieu of checking a column. 


\section{PREPARATION}

\begin{tabular}{|c|c|c|c|c|c|c|}
\hline \multirow{2}{*}{1} & The teacher was well-prepared and well-organized in class & \multirow{2}{*}{4} & \multirow{2}{*}{3} & \multirow{2}{*}{2} & \multirow{2}{*}{11} & \multirow{2}{*}{ N/A } \\
\hline & Comment: & & & & & \\
\hline \multirow{2}{*}{2} & The lesson reviewed material and looked ahead to new material & \multirow{2}{*}{4} & \multirow{2}{*}{3} & 2 & \multirow{2}{*}{1} & \multirow{2}{*}{ N/A } \\
\hline & Comment: & & & 2 & & \\
\hline \multirow{2}{*}{3} & The prepared goal/objectives were apparent & \multirow{2}{*}{4} & \multirow{2}{*}{3} & 2 & \multirow{2}{*}{1} & \multirow{2}{*}{ N/A } \\
\hline & Comment: & & & 12 & & \\
\hline
\end{tabular}

\section{PRESENTATION}

\begin{tabular}{|c|c|c|c|c|c|c|}
\hline \multirow{2}{*}{4} & The class material was explained in an understandable way. & \multirow{2}{*}{4} & \multirow{2}{*}{3} & \multirow{2}{*}{2} & \multirow{2}{*}{1} & \multirow{2}{*}{ N/A } \\
\hline & Comment: & & & & & \\
\hline \multirow{2}{*}{5} & The lesson was smooth, sequenced, and logical. & \multirow{2}{*}{4} & \multirow{2}{*}{\multicolumn{2}{|c|}{$3 \mid 2$}} & \multirow{2}{*}{1} & \multirow{2}{*}{ N/A } \\
\hline & Comment: & & & & & \\
\hline \multirow{2}{*}{6} & The lesson was well-paced & \multirow{2}{*}{\multicolumn{2}{|c|}{$-4 \mid 3$}} & \multirow{2}{*}{\begin{tabular}{l|l}
3 & 2
\end{tabular}} & \multirow{2}{*}{1} & \multirow{2}{*}{ N/A } \\
\hline & Comment: & & & & & \\
\hline \multirow[t]{2}{*}{7} & $\begin{array}{l}\text { Directions were clear and concise and students were able to carry them } \\
\text { out. }\end{array}$ & \multirow[t]{2}{*}{4} & \multirow[t]{2}{*}{3} & \multirow{2}{*}{\multicolumn{2}{|c|}{$2 \mid 1$}} & \multirow[t]{2}{*}{$\mathrm{N} / \mathrm{A}$} \\
\hline & Comment: & & & & & \\
\hline \multirow{2}{*}{8} & Material was presented at the students' level of comprehension. & \multirow{2}{*}{\multicolumn{2}{|c|}{-43}} & \multirow{2}{*}{2} & \multirow{2}{*}{1} & \multirow{2}{*}{ N/A } \\
\hline & Comment: & & & & & \\
\hline \multirow[t]{2}{*}{9} & $\begin{array}{l}\text { An appropriate percentage of the class was student production of the } \\
\text { language. }\end{array}$ & \multirow[t]{2}{*}{4} & \multirow[t]{2}{*}{3} & \multirow[t]{2}{*}{$2 \cdot 1$} & 1 & \multirow[t]{2}{*}{ N/A } \\
\hline & Comment: & & & & & \\
\hline \multirow{2}{*}{10 . } & The teacher answered questions carefully and satisfactorily. & \multirow{2}{*}{-4} & \multirow{2}{*}{\multicolumn{2}{|c|}{\begin{tabular}{l|l}
3 & 2
\end{tabular}}} & \multirow{2}{*}{ I } & \multirow{2}{*}{ N/A } \\
\hline & Comment: & & & & & \\
\hline 11 & The method(s) was(were) appropriate to the age and ability of students. & 4 & 3 & 2 & I & N/A \\
\hline & Comment: & & & & & \\
\hline 12 & The teacher knew when the students were having trouble understanding. & 4 & 3 & 2 & 1 & $\mathrm{~N} / \mathrm{A}$ \\
\hline & Comment: & & & & & \\
\hline 13 & The teacher showed an interest in, and enthusiastic for, the subject taught. & 4 & 3 & 2 & 1 & $\mathrm{~N} / \mathrm{A}$ \\
\hline & Comment: & & & & & \\
\hline
\end{tabular}




\section{EXECUTION/METHODS}

\begin{tabular}{|c|c|c|c|c|c|c|}
\hline \multirow{2}{*}{14} & There were balance and variety in activities during the lesson. & \multirow{2}{*}{4} & \multirow{2}{*}{3} & \multirow{2}{*}{2} & \multirow{2}{*}{1} & \multirow{2}{*}{$\mathrm{N} / \mathrm{A}$} \\
\hline & Comment: & & & & & \\
\hline \multirow{2}{*}{15} & The teacher was able to adapt to unanticipated situations. & \multirow{2}{*}{4} & \multirow{2}{*}{3} & \multirow{2}{*}{2} & \multirow{2}{*}{1} & \multirow{2}{*}{$\mathrm{N} / \mathrm{A}$} \\
\hline & Comment: & & & & & \\
\hline \multirow{2}{*}{16} & The material was reinforeed. & \multirow{2}{*}{-4} & \multirow{2}{*}{3} & \multirow{2}{*}{2} & \multirow{2}{*}{1} & \multirow{2}{*}{$N / A$} \\
\hline & Comment: & & & & & \\
\hline \multirow{2}{*}{17} & The teacher moved around the class and made eye contact. & \multirow{2}{*}{44} & \multirow{2}{*}{3} & \multirow{2}{*}{2} & \multirow{2}{*}{1} & \multirow{2}{*}{$N / A$} \\
\hline & Comment: & & & & & \\
\hline \multirow{2}{*}{18} & The teacher knew students' names. & \multirow{2}{*}{4} & \multirow{2}{*}{3 . } & \multirow{2}{*}{2} & \multirow{2}{*}{1} & \multirow{2}{*}{$\mathrm{N} / \mathrm{A}$} \\
\hline & Comment: & & & & & \\
\hline \multirow{2}{*}{19} & The teacher positively reinforced the students. & \multirow{2}{*}{4} & \multirow{2}{*}{3} & 2 & 1 & $N{ }^{\prime} A$ \\
\hline & Cormment: & & & 12 & 1 & $1 \mathrm{~N} / \mathrm{A}$ \\
\hline 20 & $\begin{array}{l}\text { Students' responses were effectively elicited (i.e., the order in which the } \\
\text { students were called on). }\end{array}$ & 4 & 3 & 2 & 1 & $\mathrm{~N} / \mathrm{A}$ \\
\hline & Comment: & & & & & \\
\hline 21 & Examples and illustrations were used effectively. & 4 & 3 & 7 & 1 & N WA \\
\hline 21 & Comment: & {$[4$} & 3 & 2 & 1 & $18 / \mathrm{A}$ \\
\hline 22 & Instructional aid or resource material was used effectively. & 4 & 3 & 2 & 1 & $N / A$ \\
\hline 22 & Comment: & 4 & 2 & 2 & 1 & $1 \mathrm{~N} / \mathrm{A}$ \\
\hline 23 & Drills used and presented effectively. & 4 & 3 & 2 & 1 & $N / A$ \\
\hline 23 & Comment: & 4 & 3 & 2 & 1 & $\mathbf{N} / \mathrm{A}$ \\
\hline 24 & $\begin{array}{l}\text { Structures were taken out of artificial drill contexts and applied to the real } \\
\text { contexts of the students' culture and personal experiences. }\end{array}$ & 4 & 3 & 2 & 1 & N/A \\
\hline & Comment: & & & & & \\
\hline 25 & Error perception: & 4 & 3 & 2 & 1 & $N / A$ \\
\hline $2 J$ & Comment: & 4 & 2 & 2 & 1 & $1 \times / A$ \\
\hline 26 & Appropriate error correction. & 4 & 3 & 2 & 1 & $N / A$ \\
\hline & Comment: & & & & & \\
\hline
\end{tabular}




\section{PERSONAL CHARACTERISTICS}

\begin{tabular}{|c|c|c|c|c|c|c|}
\hline \multirow{2}{*}{27} & Patience in eliciting responses. & \multirow{2}{*}{4} & \multirow{2}{*}{3.} & \multirow{2}{*}{2} & \multirow{2}{*}{1} & \multirow{2}{*}{ N/A } \\
\hline & Comment: & & & & & \\
\hline \multirow{2}{*}{28} & Clarity, tone, and audibility voice. & \multirow{2}{*}{44} & \multirow{2}{*}{3} & \multirow{2}{*}{2} & \multirow{2}{*}{1} & \multirow{2}{*}{ N/A } \\
\hline & Comment: & & & & & \\
\hline \multirow{2}{*}{29} & Personal appearance. & \multirow{2}{*}{4} & \multirow{2}{*}{3} & \multirow{2}{*}{2} & \multirow{2}{*}{1} & \multirow{2}{*}{$\mathrm{N} / \mathrm{A}$} \\
\hline & Comment: & & & & & \\
\hline \multirow{2}{*}{30} & Initiative, resourcefulness, creativity. & \multirow[t]{2}{*}{4} & \multirow{2}{*}{3} & \multirow{2}{*}{2} & \multirow{2}{*}{1} & \multirow{2}{*}{ N/A } \\
\hline & Comment: & & & & & \\
\hline \multirow[t]{2}{*}{31} & $\begin{array}{l}\text { Pronunciation, intonation, fluency, and appropriate and acceptable use of } \\
\text { language. }\end{array}$ & \multirow[t]{2}{*}{4} & \multirow[t]{2}{*}{3.} & \multirow[t]{2}{*}{2} & \multirow[t]{2}{*}{1} & \multirow[t]{2}{*}{ N/A } \\
\hline & Comment: & & & & & \\
\hline
\end{tabular}

\section{TEACHER/STUDENT INTERACTION}

\begin{tabular}{|c|c|c|c|c|c|c|}
\hline \multirow{2}{*}{32} & Teacher encouraged and assured full student participation in class. & \multirow{2}{*}{4} & \multirow{2}{*}{3} & \multirow{2}{*}{2} & \multirow{2}{*}{1} & \multirow{2}{*}{$\mathrm{N} / \mathrm{A}$} \\
\hline & Comment: & & & & & \\
\hline \multirow[t]{2}{*}{33} & $\begin{array}{l}\text { The class felt free to ask questions, to disagree, or to express their own } \\
\text { ideas. }\end{array}$ & \multirow[t]{2}{*}{4} & \multirow[t]{2}{*}{3} & \multirow{2}{*}{\multicolumn{2}{|c|}{$2 \mid 1$}} & \multirow[t]{2}{*}{$\mathbf{N} / \mathrm{A}$} \\
\hline & Comment: & & & & & \\
\hline \multirow{2}{*}{34} & The teacher was able to control and direct the class. & \multirow{2}{*}{-4} & \multirow{2}{*}{\multicolumn{2}{|c|}{\begin{tabular}{l|l}
3 & 2 \\
I
\end{tabular}}} & \multirow{2}{*}{1} & \multirow{2}{*}{$\mathrm{N} / \mathrm{A}$} \\
\hline & Comment: & & & & & \\
\hline \multirow{2}{*}{35} & The students were attentive and involved. & \multirow{2}{*}{\multicolumn{2}{|c|}{-4}} & & \multirow{2}{*}{1} & \multirow{2}{*}{ N/A } \\
\hline & Comment: & & & & & \\
\hline \multirow[t]{2}{*}{36} & $\begin{array}{l}\text { The students were comfortable and relaxed, even. during intense } \\
\text { intellectual activity. }\end{array}$ & \multirow[t]{2}{*}{4} & \multirow[t]{2}{*}{3} & 2 & \multirow[t]{2}{*}{1} & \multirow[t]{2}{*}{$\mathrm{N} / \mathrm{A}$} \\
\hline & Comment: & & & & & \\
\hline \multirow{2}{*}{37} & The students were treated fairly, impartially, and with respect. & \multirow{2}{*}{\multicolumn{2}{|c|}{1}} & \multirow{2}{*}{\begin{tabular}{l|l}
3 & 2 \\
\end{tabular}} & \multirow{2}{*}{1} & \multirow{2}{*}{$\mathrm{N} / \mathrm{A}$} \\
\hline & Comment: & & & & & \\
\hline \multirow{2}{*}{38} & The students were encouraged to do their best. & \multirow{2}{*}{\multicolumn{2}{|c|}{. }} & & \multirow{2}{*}{1} & \multirow{2}{*}{ N/A } \\
\hline & Comment: & & & & & \\
\hline 39 & The teacher was relaxed and matter-of-fact in voice and manner. & 44 & 3 & 2 & 1 & $\mathbf{N} / A$ \\
\hline & Comment: & & & & & \\
\hline 40 & The teacher was aware of individual and group needs. & -4 & 3 & 2 & 1 & $N / A$ \\
\hline & Comment: & & & & & \\
\hline 41 & Digressions were used positively and not overused. & -4 & 3 & 2 & 1 & $\mathrm{~N} / \mathrm{A}$ \\
\hline & Comment: & & & & & \\
\hline
\end{tabular}




\section{Conclusion and suggestion}

In regards to professional development, cooperative learning principles have been proposed as an altemate way or means of upgrading teacher's professionalism which can be conducted within the teacher's immediate institution along with other teachers from the same school. This is not only accessible and less threatening, but also contextualized as it addresses the needs and the characteristics of the immediate school communities.

Ideally, it is recommended that school administrative and principal are also involved, especially in initiating and setting the tone of or even working along with the teachers to sustain such development program.

Current theory generated from research on effective school practices all argue in favor of using cooperative learning in staff development, and in general the value of following Vygotskian principles in helping educators of any age practice the value of learning from one another (Geary,1999, p.13)

\section{Bibliography}

Brown, Douglas H.(2001) Teaching by Principles. San Francisco: Longman

Elliot, J. (1993). Action Research for Educational Change, Bristol: Open University Press.

Davies, Paul. (2000). Success in English Teaching. Oxford: Oxford University Press

Diaz-Maggioli. H. Gabriel. (2003). Professional Developmentfor Language Teachers. Online Resouces: DIGESTS

Geary, T. William (1999). Staff Development in Cooperative Learning for Inservice Teachers, Quebec: University of Hawaii

Hanson, E.M. (1991). Educational Administration and organizational behavior $\left(3^{\text {rd }}\right.$ ed.) Boston: Allyn and Bacon

Harmer, Jeremy (2005). The Practice of English Language Teaching, Cambridge: Pearson Longman.

Kessler, Carolyn. (1992). Cooperative Language Learning: A Teacher's Resource Book. New Jersey: Prentice Ha

- Reimers, Eleonora Villegas. (2003). Teacher Professional Development: an international review of the literature. UNESCO

-Wallace, M.J. (1998). Action Research fȫ Language Teachers._Australia: Cambridge University Press. 